\section{Retinol binding protein \\ 4 and incident diabetes - \\ the Atherosclerosis Risk in \\ Communities Study (ARIC Study)}

\section{Proteína carreadora de retinol $4 e$ diabetes incidente - Atherosclerosis Risk in Communities Study (ARIC Study)}

Vivian C. Luft'
Mark Pereira"

James S. Pankow"

Christie Ballantyne"I'

David Couperiv

Gerardo Heissv

Bruce B. Duncan ${ }^{\prime, V}$

for the ARIC Investigators

' Graduate Studies Program in Epidemiology, School of Medicine, Federal University of Rio Grande do Sul, Porto Alegre, RS, Brazil

"Division of Epidemiology \& Community Health, School of Public Health and Community Health, University of Minnesota, Minneapolis, MN, U.S.A.

"'Department of Medicine, Baylor College of Medicine, Houston, TX, U.S.A.

Iv Department of Biostatistics, Gillings School of Global Public Health, University of North Carolina, Chapel Hill, NC, U.S.A.

v Department of Epidemiology, Gillings School of Global Public Health, University of North Carolina, Chapel Hill, NC, U.S.A.

Funding for this study was provided by National Institute of Diabetes and Digestive and Kidney Diseases Grant R01-DK56918 and by National Heart, Lung, and Blood Institute Contracts N01HC-55015, N01-HC-55016, N01-HC-55018, N01-HC-55019, N01-HC-55020, N01-HC-55021, and N01-HC-55022.

Corresponding author: Vivian C. Luft. Programa de Pós-graduação em Epidemiologia, Universidade Federal do Rio Grande do Sul. Rua Ramiro Barcelos, 2.400, 90035-003 Porto Alegre, RS, Brazil. E-mail:vivi_luft@yahoo.com.br

\section{Abstract}

Background: Retinol binding protein 4 (RBP4) has been described as a link between impaired glucose uptake in adipocytes and systemic insulin sensitivity. Objective: To determine whether RBP4 fasting levels predict the development of type 2 diabetes. Methods: Using a case-cohort design, we followed 543 middle-aged individuals who developed diabetes and 537 who did not over $\sim 9$ years within the populationbased Atherosclerosis Risk in Communities Study. Weighted Cox proportional hazards analyses permitted statistical inference of the RBP4 - incident diabetes associations to the entire cohort. Results: Women in the highest tertile of RBP4 presented greater risk of developing diabetes $(\mathrm{HR}=1.74$; $95 \%$ CI $1.03-2.94$ ) in analyses adjusted for age, ethnicity, study center, parental history of diabetes, hypertension, glomerular filtration rate, body mass index, waist-hip ratio, nonesterified fatty acids, adiponectin, leptin, triglycerides and HDL-C. When additionally adjusted for fasting insulin, this association's significance became borderline $(\mathrm{HR}=1.68$; 95\%CI $1.00-2.82)$. No association between RBP4 levels and incident diabetes was found in men. Conclusion: These findings suggest that RBP4 levels may be directly involved in the pathogenesis of type 2 diabetes in women.

Keywords: Diabetes. Retinol-Binding Proteins. RBP4 protein, human. Epidemiologic Studies. 


\section{Resumo}

Introdução: A proteína carreadora de retinol 4 (RBP4) tem sido descrita como elo entre uma menor captura de glicose pelos adipócitos e sensibilidade sistêmica à insulina. Objetivo: Determinar se os níveis de RBP4 em jejum predizem diabetes tipo 2. Método: Em um delineamento de caso-coorte, foram acompanhados 543 indivíduos de meia-idade que desenvolveram diabetes e 537 que não desenvolveram diabetes ao longo de 9 anos no estudo Atherosclerosis Risk in Communities Study (ARIC). Foi realizada análise ponderada de riscos proporcionais de Cox para inferência estatística da associação entre os níveis de RBP4 e diabetes incidente na coorte. Resultados: Mulheres com níveis de RBP4 no terceiro tercil apresentaram maior risco de desenvolver diabetes (HR $=1,74 ; 95 \%$ CI 1,03-2,94) em análises ajustadas para idade, etnia, centro, história familiar de diabetes, hipertensão, taxa de filtração glomerular, índice de massa corporal, razão cintura-quadril, níveis de ácidos graxos não esterificados, adiponectina, leptina, triglicerídeos e HDL-C. Quando adicionalmente ajustado para os níveis de insulina de jejum, a significância dessa associação se tornou limítrofe (HR = 1,68; $95 \%$ CI 1,00-2,82). Nenhuma associação foi observada entre RBP4 e diabetes incidente em homens. Conclusão: Esses achados sugerem que os níveis de RBP4 possam estar diretamente envolvidos na patogênese do diabetes tipo 2 em mulheres.

Palavras-chave: Diabetes. Proteína carreadora de retinol. RBP4. Estudo epidemiológico.

\section{Introduction}

Type 2 diabetes is a leading cause of morbidity and mortality ${ }^{1}$. It results in a considerably reduced life expectancy, diminished quality of life, and enormous health costs ${ }^{2}$. Improving our understanding of the molecular biology underlying type 2 diabetes will hopefully lead to more efficient prevention and more efficacious treatment.

Retinol binding protein 4 (RBP4) is the principal transport protein for retinol (vitamin A) in the circulation. However, there is no compelling evidence that dietary vitamin A regulates circulating levels of RBP4. Some studies have shown that high fasting levels of RBP4 are associated with insulin resistance and diabetes ${ }^{3,4}$, although the molecular mechanisms underlying this effect are not clearly understood ${ }^{5}$. This association was first demonstrated in mice, where increases in RBP4 through genetic manipulation or injection caused insulin resistance ${ }^{3}$. In humans, although findings are not entirely consistent ${ }^{6,7}$, serum levels of RBP4 have been shown to be elevated with obesity and type 2 diabetes, and changes in insulin sensitivity in response to exercise training were associated with changes in RBP4 levels 4 .

To clarify the predictive role of RBP4 on diabetes pathogenesis, ethnically diverse prospective studies, well-suited to minimize bias and control for confounding are needed. In the present study, we tested the hypothesis that higher fasting plasma RBP4 concentrations predict the development of type 2 diabetes in a long-term cohort of middle-aged adults.

\section{Methods}

Between 1987 and 1989, the Atherosclerosis Risk in Communities (ARIC) study recruited a population-based cohort of 15,792 men and women aged 45-64 years from four US communities. The ARIC was designed to investigate the etiology and natural history of atherosclerosis, the etiology of clinical atherosclerotic diseases, 
and variation in cardiovascular risk factors, medical care and disease by ethnic group, gender, location, and date. For the present analyses, we used a case-cohort design, as previously described in the investigation of the role of several inflammation biomarkers in the development of diabetes in the ARIC Study ${ }^{8-10}$. Prior to sampling, we excluded 2,018 participants with prevalent diabetes, 95 members of minority ethnic groups with small numbers, 853 individuals who did not return to any follow-up visits, 26 with no valid diabetes determination at follow-ups, 7 with restrictions on stored plasma use, 12 with missing baseline anthropometric measurements, 2,506 participants in previous ARIC case-control and case-cohort studies involving cardiovascular disease for whom stored plasma was either previously exhausted or held in reserve, 45 participants with incomplete fasting $(<8 \mathrm{~h}), 490$ not havingvalues for all covariates, and 31 for whom RBP4 was not measured. From the 9729 eligible individuals, we selected ethnicity-stratified (50\% African-American, $50 \%$ white) random samples of both incident diabetes (cases) and members of the full eligible ARIC cohort, resulting in 1095 individuals. We additionally excluded 15 individuals having missing data for inflammation markers, non-esterified fatty acid or alcohol intake. Our final sample was composed by 543 diabetes cases and 537 non-cases. A few of the incident cases of diabetes overlapped with the cohort random sample (full cohort-representative random sample $=630$ ). Incident diabetes was defined on the basis of a reported physician diagnosis, use of antidiabetic medications, or a fasting glucose value $\geq 7.0 \mathrm{mmol} / \mathrm{l}$ at 3 follow-up visits, each occurring approximately 3 years after the previous one. The date of diabetes incidence was estimated by linear interpolation using glucose values at the ascertaining visit and the prior one, as previously described ${ }^{8}$. Cohort-representative controls were followed for a median of 9 years, and incident cases were followed until the onset of diabetes (median $=3$ years).

Human-subject research review committees at the involved institutions approved the study, and all participants gave written informed consent.

RBP4 was measured in duplicate using an ELISA technique (R\&D Systems). These samples, stored for approximately 20 years at $-70^{\circ} \mathrm{C}$, were thawed and maintained at $4^{\circ} \mathrm{C}$ until measured, no longer than $24 \mathrm{~h}$ later. Analysis of replicate pair samples drawn at baseline from a subset of 39 subjects yielded a reliability coefficient of 0.93 and a coefficient of variation of $8.9 \%$ for RBP4. Laboratory measurements and reliability coefficients, as well as methods for measurement of other covariates, are described in previous reports ${ }^{8-10}$. Low-grade systemic inflammation is estimated by a score ranging from 0 to 6 , attributing one point for a value greater than the median of the cohort sample for each of the measured inflammation markers (IL-6, CRP, orosomucoid, and sialic acid, and white cell count and fibrinogen) ${ }^{8}$.

Glomerular filtration rate (GFR) was estimated using the CKD-EPI serum creatinine equation, considering gender, ethnicity and age ${ }^{11}$.

We used weighted Spearman correlations to describe crude associations between RBP4 and other variables, and weighted ANCOVA to compute adjusted RBP-4 means in diabetes cases and non-cases. We performed weighted Cox proportional hazards regression to estimate the relation between plasma RBP4 and time of onset of diabetes, with weights defined as the inverse of the ethnicity-specific sampling fractions to enable estimation and inference relevant to the entire eligible cohort. In proportional hazard analyses, leptin gender-specific quartiles were modeled as a continuous variable $^{10}$. Adiponectin, body mass index, waist-hip ratio and other continuous variables were centered on their means in order to avoid multicollinearity. Centering was performed subtracting from each observed value the mean of the variable in question and then dividing the difference by the standard deviation of the variable's distribution: (observed - mean) / standard deviation. To test heterogeneity in the RBP4 - incident diabetes associations across categories of 
covariates, we characterized RBP4 in tertiles (according to the cohort random sample distribution) and tested the interactions in the final model.

Linear trend was tested by fitting tertiles of RBP4 as a continuous variable in the regression models. Statistical analyses were performed using the SAS (SAS Institute Inc., Cary, NC) and SUDAAN (Research Triangle Institute, Raleigh, NC) statistical software packages, reflecting the case-cohort sampling design. The proportional hazards assumption was examined through plots of Martingale and Schoenfeld residuals ${ }^{12}$. Collinearity across independent variables was investigated with linear regression models: variance inflation factors were $<2.5$.

\section{Results}

Among incident diabetes cases, median age (interquartile ranges) was 53 (49-58) years, there were 76 (13\%) African-American men, 201 (35\%) African-American women, $153(26 \%)$ white men and 151 (26\%) white women. Among non-cases, median age was 52 (48-57) years, and the corresponding numbers were 75 (14\%), 164 (30\%), 117 (21\%) and 189 (35\%), respectively. Other characteristics of cases and cohort representative non-cases have previously been reported ${ }^{9}$. RBP4 distribution, expressed by mean values and standard deviations, in diabetes cases and non-cases was $29.2 \pm$ $8.2 \mathrm{~g} / \mathrm{mL}$ and $31.3 \pm 8.9 \mathrm{~g} / \mathrm{mL}$, respectively. Spearman correlations assessed in the cohort random sample $(n=630)$ showed that RBP4 levels were most highly correlated with triglycerides $(\mathrm{r}=0.37, \mathrm{p}<0.01)$, kidney function markers (serum creatinine, $r$ $=0.34, \mathrm{p}<0.01$; glomerular filtration rate, $\mathrm{r}=-0.21, \mathrm{p}<0.01)$, and central obesity (waist-hip ratio, $\mathrm{r}=0.26, \mathrm{p}<0.01$ ); and to a lesser, yet still statistically significant, extent with fasting insulin $(r=0.08, p=0.03)$, the adipokines adiponectin $(\mathrm{r}=-0.15, \mathrm{p}<$ $0.01)$ and leptin $(r=-0.13, p<0.01)$, some inflammation markers (orosomucoid, sialic acid, and white blood count), other metabolic variables (non-esterified fatty acids, HDL-cholesterol), blood pressure, glucose, habitual ethanol intake, and cigarette smoking. Important differences in association were seen across gender/ethnic groups, indicating potential for confounding (Table 1).

RBP4 mean values were somewhat higher in men than women (32.3 vs. 27.8 $\mathrm{g} / \mathrm{mL}, \mathrm{p}<0.01$ ), African-Americans than whites (30.9 vs. $29.1 \mathrm{~g} / \mathrm{mL}, \mathrm{p}=0.03$ ), and in those in the lowest (vs. the highest) quartile of glomerular filtration rate (32.1 vs. $28.6 \mathrm{~g} /$ $\mathrm{mL}, \mathrm{p}<0.01$ ), independently of studied confounders (Table 2).

Women who developed diabetes had higher RBP4 mean levels at baseline: 29.3 (95\%CI $28.1-30.6) \mathrm{g} / \mathrm{mL}$ vs. 27.8 (95\% CI $27.2-28.4) \mathrm{g} / \mathrm{mL}(\mathrm{p}=0.03)$, adjusted for age, ethnic group, parental history of diabetes, ethanol intake, smoking, hypertension, body mass index (BMI) and waist-hip ratio, an inflammation score ${ }^{8}$, adiponectin, leptin, triglycerides, HDL-cholesterol, non-esterified fatty acids, insulin and glucose levels. This difference was not observed in men: 33.0 (95\% CI: 31.7-34.4) g/mL vs. 32.5 (95\%CI: $31.6-33.4) \mathrm{g} / \mathrm{mL}(\mathrm{p}=0.56)$.

Survival analyses comparing the highest (vs. lowest) RBP4 quartile in all individuals indicated no overall association with diabetes when adjusted for age, ethnic group, ethanol intake, smoking, BMI and waist-hip ratio $(\mathrm{HR}=1.26,95 \% \mathrm{CI} 0.82-1.92, \mathrm{p}=0.29$ ). The size of the association diminished further when additionally adjusted for other covariates (parental history of diabetes, hypertension, glomerular filtration rate, inflammation score ${ }^{8}$, adiponectin, leptin, triglycerides, HDL-cholesterol, and non-esterified fatty acids): $\mathrm{HR}=1.09,95 \% \mathrm{CI}$ 0.66-1.80 ( $\mathrm{p}=0.73)$. In analyses stratified by gender (Table 3), even though gender interaction was not statistically significant ( $\mathrm{p}=0.51$ ), women presenting RBP4 levels at the highest tertile were at increased risk of diabetes, while no association between RBP4 and diabetes was observed in men. Table 3 also shows that, in women, the association between RBP4 and diabetes was significant independently of multiple 
Table 1 - Spearman correlations for crude associations of RBP4 levels with inflammation and metabolic variables at baseline in the cohort random sample.

Tabela 1 - Correlações de Spearman para associações brutas entre níveis de RBP4 com inflamação e outras variáveis metabólicas, na linha de base, na amostra aleatória da coorte.

\begin{tabular}{|c|c|c|c|c|c|}
\hline & Overall & $\begin{array}{l}\text { White } \\
\text { Women } \\
(n=206)\end{array}$ & $\begin{array}{l}\text { African-American } \\
\text { Women } \\
(n=208)\end{array}$ & $\begin{array}{c}\text { White } \\
\text { Men } \\
(n=131)\end{array}$ & $\begin{array}{c}\text { African-American } \\
\text { Men } \\
(\mathrm{n}=85)\end{array}$ \\
\hline & $r$ & $\mathrm{R}$ & r & r & r \\
\hline \multicolumn{6}{|l|}{ Possible confounders } \\
\hline Age (years) & 0.20 & 0.34 & 0.19 & -0.01 & 0.06 \\
\hline Usual ethanol intake (g/wk) & 0.16 & 0.00 & 0.05 & 0.12 & 0.38 \\
\hline $\mathrm{N}$ cigarettes per day ${ }^{*} \mathrm{~N}$ years of smoking & 0.15 & 0.08 & 0.16 & -0.04 & 0.09 \\
\hline Body mass index $\left(\mathrm{kg} / \mathrm{m}^{2}\right)$ & 0.05 & 0.10 & 0.05 & -0.05 & -0.13 \\
\hline Waist (cm) & 0.14 & 0.14 & 0.09 & 0.05 & -0.08 \\
\hline Waist-to-hip ratio & 0.26 & 0.21 & 0.12 & 0.07 & 0.19 \\
\hline Creatinine (mg/dL) & 0.34 & 0.20 & 0.37 & 0.23 & 0.07 \\
\hline GFR (mL/min per $\left.1.73 \mathrm{~m}^{2}\right)$ & -0.21 & -0.26 & -0.38 & -0.21 & -0.12 \\
\hline \multicolumn{6}{|l|}{ Inflammation markers and adipokines } \\
\hline C-reactive protein $(\mathrm{mg} / \mathrm{mL})$ & -0.03 & 0.13 & 0.03 & -0.26 & -0.10 \\
\hline IL-6 (pg/mL) & -0.09 & -0.01 & -0.07 & -0.27 & -0.10 \\
\hline Fibrinogen ( $\mu \mathrm{mol} / \mathrm{L})$ & -0.05 & 0.04 & 0.06 & -0.12 & -0.07 \\
\hline Orosomucoid (mg/dL) & 0.13 & 0.13 & 0.25 & 0.09 & 0.28 \\
\hline Sialic acid (mg/dL) & 0.15 & 0.21 & 0.11 & 0.18 & -0.08 \\
\hline White blood count $\left(10^{9} / L\right)$ & 0.09 & 0.05 & 0.12 & 0.03 & 0.12 \\
\hline Complement component 3 (mg/dL) & 0.08 & 0.20 & 0.17 & 0.01 & -0.01 \\
\hline Adiponectin (ug/mL) & -0.15 & -0.05 & -0.04 & -0.10 & -0.20 \\
\hline Leptin $(\mathrm{ng} / \mathrm{mL})$ & -0.13 & 0.17 & 0.00 & 0.06 & 0.00 \\
\hline \multicolumn{6}{|l|}{ Other metabolic variables } \\
\hline Non-esterified fatty acids (mEq/L) & 0.10 & 0.24 & 0.05 & 0.12 & 0.25 \\
\hline Triglycerides (mmol/L) & 0.37 & 0.34 & 0.32 & 0.34 & 0.25 \\
\hline HDL-cholesterol (mg/dL) & -0.08 & 0.09 & -0.04 & -0.04 & 0.11 \\
\hline Systolic blood pressure (mmHg) & 0.13 & 0.18 & 0.00 & 0.06 & 0.17 \\
\hline Diastolic blood pressure (mmHg) & 0.08 & 0.07 & -0.02 & 0.00 & 0.29 \\
\hline Fasting insulin $(\mu \mathrm{U} / \mathrm{mL})$ & 0.08 & 0.18 & 0.08 & 0.03 & -0.07 \\
\hline HOMA-IR & 0.09 & 0.19 & 0.10 & 0.04 & -0.05 \\
\hline Fasting glucose (mg/dL) & 0.12 & 0.11 & 0.13 & 0.04 & 0.09 \\
\hline
\end{tabular}

Bolding indicate $p$ value $<0.05$. GFR - Glomerular filtration rate ${ }^{13}$.

Negrito indica valor $p<0,05$. GFR - Taxa de filtração glomerular ${ }^{13}$

diabetes risk factors $(\mathrm{HR}=1.74,95 \% \mathrm{CI}$ 1.03-2.94, comparing the highest vs. lowest RBP4 tertile). Statistical significance became borderline when additionally adjusted for fasting insulin ( $\mathrm{HR}=1.68$; 95\% CI 1.00-2.82), a marker of insulin resistance presumably on the RBP4-diabetes causal pathway, and it was not nominally statistically significant when baseline fasting glucose was added to the model (HR $=1.24,95 \%$ CI 0.70-2.19).

No heterogeneity in these associations was found comparing African-Americans 
Table 2 - RBP4 levels at baseline in the cohort random sample.

Tabela 2 - Níveis de RBP4, na linha de base, na amostra aleatória da coorte.

\begin{tabular}{|c|c|c|c|c|c|}
\hline & & \multicolumn{2}{|c|}{ Minimal adjustment } & \multicolumn{2}{|c|}{ Full adjustment } \\
\hline & & Mean $(95 \% \mathrm{Cl}), \mathrm{g} / \mathrm{mL}$ & $p$ value & Mean $(95 \% \mathrm{Cl}), \mathrm{g} / \mathrm{mL}$ & $p$ value \\
\hline \multirow[t]{2}{*}{ Gender } & Female & $27.8(27.0-28.7)$ & $<0.01$ & $27.8(27.1-28.6)$ & $<0.01$ \\
\hline & Male & $32.3(31.2-33.3)$ & & $32.3(31.2-33.5)$ & \\
\hline \multirow[t]{2}{*}{ Ethnicity } & African-American & $29.2(28.1-30.3)$ & 0.73 & $30.9(29.5-32.2)$ & 0.03 \\
\hline & White & $29.5(28.7-30.2)$ & & $29.1(28.5-29.8)$ & \\
\hline \multirow[t]{2}{*}{ Age } & $45-54$ years & $26.7(24.7-28.7)$ & $<0.01$ & $29.9(28.1-31.7)$ & 0.58 \\
\hline & $55-64$ years & $28.7(27.9-29.5)$ & & $29.6(28.9-30.3)$ & \\
\hline \multirow[t]{2}{*}{ Ethanol ( $4^{\text {th }}$ quartile) $)^{\mathrm{a}}$} & Yes & $31.2(29.7-32.8)$ & $<0.01$ & $30.6(29.2-31.9)$ & 0.06 \\
\hline & No & $28.9(28.1-29.6)$ & & $29.1(28.5-29.7)$ & \\
\hline \multirow[t]{2}{*}{ GFR (1 $1^{\text {st }}$ quartile $)^{b}$} & Yes & $31.9(30.5-33.4)$ & $<0.01$ & $32.1(30.9-33.3)$ & $<0.01$ \\
\hline & No & $28.6(27.9-29.3)$ & & $28.6(28.0-29.2)$ & \\
\hline \multirow[t]{3}{*}{ Smoking } & Current & $29.7(28.1-31.3)$ & $<0.01$ & $29.6(28.2-31.0)$ & 0.12 \\
\hline & Former & $31.3(30.0-32.5)$ & & $30.2(29.2-31.2)$ & \\
\hline & Never & $28.1(27.2-29.1)$ & & $28.9(28.1-29.7)$ & \\
\hline \multirow[t]{2}{*}{ Inflammation score ${ }^{8}$} & High & $29.5(28.5-30.6)$ & 0.77 & $28.9(28.1-29.7)$ & 0.11 \\
\hline & Low & $29.3(28.5-30.1)$ & & $29.8(29.1-30.4)$ & \\
\hline \multirow[t]{3}{*}{ Body mass index } & Normal & $29.3(28.1-30.4)$ & 0.86 & $30.1(28.9-31.2)$ & 0.30 \\
\hline & Overweight & $29.4(28.6-30.2)$ & & $29.0(28.3-29.7)$ & \\
\hline & Obese & $29.8(28.3-31.2)$ & & $29.3(27.8-30.7)$ & \\
\hline \multicolumn{6}{|l|}{ WHRc } \\
\hline \multirow[t]{2}{*}{ Men } & Yes & $33.1(31.5-34.8)$ & 0.26 & $33.2(31.9-34.6)$ & 0.15 \\
\hline & No & $31.9(30.6-33.3)$ & & $31.9(30.7-33.0)$ & \\
\hline \multirow[t]{2}{*}{ Women } & Yes & $28.5(27.3-29.7)$ & 0.08 & $27.9(26.9-28.9)$ & 0.61 \\
\hline & No & $27.0(25.9-28.1)$ & & $27.5(26.7-28.4)$ & \\
\hline \multirow[t]{3}{*}{ Fasting insulin ${ }^{d}$} & $<\mathrm{P} 25$ & $28.3(26.7-29.9)$ & 0.30 & $28.5(27.1-29.9)$ & 0.06 \\
\hline & P25 - P75 & $29.7(28.8-30.5)$ & & $30.0(29.3-30.6)$ & \\
\hline & $>$ P75 & $29.7(28.5-31.0)$ & & $28.8(27.5-30.1)$ & \\
\hline
\end{tabular}

${ }^{\mathrm{a}}$ Ethanol intake $\geq 52.8 \mathrm{~g}$ per week; ${ }^{a}$ Ingestão de álcool $\geq 52,8 \mathrm{~g}$ por semana.

${ }^{\mathrm{b}}$ Glomerular filtration rate $<61.8 \mathrm{~mL} / \mathrm{min}$ per $1.73 \mathrm{~m}^{2}$; ${ }^{\circ}$ Taxa de filtração glomerular $<61,8 \mathrm{~mL} / \mathrm{min}$ por $1,73 \mathrm{~m}^{2}$.

' Waist-to-hip ratio $\geq 0.95$, for men, or $\geq 0.89$, for women; ${ }^{c}$ Razão cintura-quadril $\geq 0,95$ para homens ou $\geq 0,89$ para mulheres.

d Percentile $25=5 \mu \mathrm{U} / \mathrm{mL}$, Percentile $75=13 \mu \mathrm{U} / \mathrm{mL}^{\text {i }}{ }^{d}$ Percentil $25=5 \mu \mathrm{U} / \mathrm{mL}$, Percentil $75=13 \mu \mathrm{U} / \mathrm{mL}$.

Minimal adjustment: Adjusted for age, gender, and ethnic group/centre indicators;

Ajuste mínimo: Ajustado para idade, sexo e etnia/centro.

Full adjustment: Adjusted for age, gender, ethnic group/centre indicators, plus ethanol intake, ethanol intake ${ }^{2}, \mathrm{~N}$ cigarettes per day * $\mathrm{N}$ years of smoking, BMI, $\mathrm{BMI}^{2}$, waist-to-hip ratio, glomerular filtration rate, inflammation score ${ }^{8}$, adiponectin, leptin (gender-specific quartiles), In-triglycerides, In-triglycerides ${ }^{2}$, HDLcholesterol, non-esterified fatty acids, hypertension, family history of diabetes, In-insulin, and glucose.

Ajuste máximo: Ajustado idade, sexo e etnia/centro, consumo de etanol ${ }^{2}$, número de cigarros por dia * número de anos de tabagismo, índice de massa corporal ${ }^{2}$ razão cintura-quadril, taxa de filtração glomerular, escore de inflamação ${ }^{8}$, adiponectina, leptina (quartis específicos por sexo), In-triglicerídeos ${ }^{2}$, HDL-c, ácidos graxos não esterificados, hipertensão, história familiar de diabetes, In-insulina e glicose

and whites, obese and non-obese individuals, current smokers and non-smokers, or in those with a higher vs. lower inflammation score $^{8}$, glomerular filtration rate, or ethanol intake [data not shown]. Women having impaired fasting glucose at baseline showed a considerably smaller RBP4-diabetes association ( $\mathrm{HR}=1.24$, CI 95\% 0.62-2.47) than those with baseline normoglycemia $(\mathrm{HR}=2.38$, CI 95\% 0.83-6.77), though this 
Table 3 - Hazard ratios (95\% Cls) of incident diabetes by tertiles of RBP4,stratified by gender.

Tabela 3 - Razão de riscos proporcionais de Cox (Hazard Ratios, 95\% CI) para diabetes incidente de acordo com os níveis de RBP4, estratificado por sexo.

\begin{tabular}{|c|c|c|c|c|c|c|}
\hline & \multicolumn{3}{|c|}{ Men } & \multicolumn{3}{|c|}{ Women } \\
\hline & $2^{\text {nd }}$ tertile & $3^{\text {rd }}$ tertile & Linear trend & $2^{\text {nd }}$ tertile & $3^{\text {rd }}$ tertile & Linear trend \\
\hline & $\mathrm{HR}(95 \% \mathrm{Cl})$ & $\mathrm{HR}(95 \% \mathrm{Cl})$ & $p$ value & $\mathrm{HR}(95 \% \mathrm{Cl})$ & $\mathrm{HR}(95 \% \mathrm{Cl})$ & $p$ value \\
\hline Model 1 & $0.96(0.59-1.57)$ & $1.07(0.66-1.73)$ & 0.77 & $1.48(1.01-2.16)$ & $1.92(1.32-2.79)$ & $<0.01$ \\
\hline Model 2 & $1.02(0.62-1.69)$ & $1.12(0.67-1.85)$ & 0.67 & $1.49(1.01-2.18)$ & $1.94(1.33-2.83)$ & $<0.01$ \\
\hline Model 3 & $0.89(0.51-1.56)$ & $1.00(0.58-1.71)$ & 0.93 & $1.26(0.82-1.92)$ & $1.70(1.11-2.59)$ & 0.01 \\
\hline Model 4 & $0.89(0.51-1.56)$ & $1.03(0.60-1.77)$ & 0.90 & $1.27(0.83-1.94)$ & $1.83(1.19-2.82)$ & 0.01 \\
\hline Model 5 & $0.98(0.54-1.76)$ & $0.94(0.51-1.73)$ & 0.83 & $1.27(0.79-2.03)$ & $1.74(1.03-2.94)$ & 0.04 \\
\hline Model 6 & $1.01(0.57-1.80)$ & $0.93(0.51-1.71)$ & 0.83 & $1.28(0.81-2.04)$ & $1.68(1.00-2.82)$ & 0.05 \\
\hline Model 7 & $1.04(0.56-1.92)$ & $0.83(0.44-1.57)$ & 0.57 & $1.12(0.67-1.85)$ & $1.24(0.70-2.19)$ & 0.47 \\
\hline
\end{tabular}

Reference: $1^{\text {st }}$ tertile. / Referência: $1^{\circ}$ tercil.

In men: $1^{\text {st }}$ tertile $=12.8-28.1 \mathrm{~g} / \mathrm{mL}, 2^{\text {nd }}$ tertile $=28.2-35.1 \mathrm{~g} / \mathrm{mL}, 3^{\text {rd }}$ tertile $=35.2-59.2 .1 \mathrm{~g} / \mathrm{mL} . /$ Em homens: $1^{\circ}$ tercil $=12,8-28,1 \mathrm{~g} / \mathrm{mL}, 2^{\circ}$ tercil $=28,2-35,1 \mathrm{~g} /$ $\mathrm{ml}, 3^{\circ}$ tercil $=35,2-59,2 \mathrm{~g} / \mathrm{mL}$

In women: $1^{\text {st }}$ tertile $=8.8-23.9 \mathrm{~g} / \mathrm{mL}, 2^{\text {nd }}$ tertile $=24.0-30.1 \mathrm{~g} / \mathrm{mL}, 3^{\text {rd }}$ tertile $=30.3-70.0 \mathrm{~g} / \mathrm{mL} . /$ Em mulheres: $1^{\circ}$ tercil $=8,8-23,9 \mathrm{~g} / \mathrm{mL}, 2^{\circ}$ tercil $=24,0-30,1 \mathrm{~g} / \mathrm{mL}$, $3^{\circ}$ tercil $=30,3-70,0 \mathrm{~g} / \mathrm{mL}$.

Model 1: Adjusted for age, ethnic group/centre indicators. / Modelo 1: ajustado para idade, sexo e etnia/centro.

Model 2: Model 1 plus ethanol intake, ethanol intake ${ }^{2}$, and $\mathrm{N}$ cigarettes per day * $\mathrm{N}$ years of smoking. / Modelo 2: Modelo $1+$ consumo de etanol$^{2}$, número de cigarros por dia * número de anos de tabagismo.

Model 3: Model 2 plus BMI, BMI², and waist-to-hip ratio./ Modelo 3: Modelo 2 + índice de massa corporal', razão cintura-quadril.

Model 4: Model 3 plus glomerular filtration rate. / Modelo 4: Modelo $3+$ taxa de filtração glomerular.

Model 5: Model 4 plus inflammation score ${ }^{8}$, adiponectin, leptin (gender-specific quartiles), In-triglycerides ${ }^{2}$, HDL-cholesterol, non-esterified fatty acids, hypertension, and family history of diabetes. / Modelo 5: Modelo $4+$ escore de inflamação ${ }^{8}$, adiponectina, leptina (quartis específicos por sexo), In-triglicerídeos ${ }^{2}$, HDL-c, ácidos graxos não esterificados, hipertensão, história familiar de diabetes.

Model 6: Model 5 plus In-insulin./ Modelo 6: Modelo $5+$ In-insulina.

Model 7: Model 6 plus glucose. / Modelo 7:Modelo 6 + glicose.

difference was not statistically significant $(\mathrm{p}$ $=0.47)$. Excluding 27 individuals identified as non-cases but having 2-h glycaemia $\geq 11.1$ $\mathrm{mmol} / \mathrm{l}$ during the oral glucose tolerance test performed at the last follow-up visit did not materially alter the results [data not shown].

\section{Discussion}

In this case cohort study of middle-aged African-Americans and whites, RBP4 was correlated with several metabolic variables and inflammation markers, most notably so with triglycerides, waist-hip ratio and creatinine. It was minimally correlated with fasting insulin. Values were higher in men than women. Though no association was found in the overall sample, higher RBP4 values predicted the development of diabetes in women in multivariable-adjusted analyses.

It has been suggested that adipocytes detect decreased glucose uptake in early insulin resistance and, in response, secrete adipokines such as RBP4 to restrict glucose uptake in skeletal muscle and increase glucose production in the liver, thereby increasing the blood glucose level, as a consequence of the "adipocytes' starvation state"13,14. RBP4 appears to reduce glucose uptake in the muscle tissue by interfering with the phosphorylation of the insulin receptor substrate-1 (IRS-1) and phosphoinositide-3-kinase (PI-3-kinase) activity, which are necessary components of the insulin signaling pathway, while, in the liver, RBP4 has been shown to increase the expression of the gluconeogenic enzyme phosphoenol-pyruvate carboxykinase (PEPCK), resulting in increased hepatic glucose output ${ }^{3}$. In addition to this, it has been also proposed that oversecretion of RBP4 may adversely affect B-cell function ${ }^{15}$, although mechanisms for such an action remain to be described and other authors have failed in the attempt to confirm this hypothesis ${ }^{16,17}$. 
Several other studies have tried to elucidate the association between RBP4 and diabetes in humans, yielding conflicting results ${ }^{4,6,7,18-20}$. These inconsistencies likely result from differences in study design, sample size, population composition, and assay methods used. Analytical strategies are also important. An advantage of our study is the ability to adjust our results for many factors that may influence RBP4 levels (such as ethanol intake and kidney function) and factors associated with diabetes, previously suggested to be possible confounders in the RBP4-diabetes association ${ }^{6}$.

In agreement with the present findings, other studies have demonstrated lower RBP4 levels in women compared to men ${ }^{18,19}$, but, to our knowledge, we are the first group to demonstrate that gender may modify the ability of RBP4 to predict diabetes. Possible reasons exist to explain why the RBP4-diabetes association may be different between men and women, especially in middle age. First, metabolic differences between genders has been described to impact on insulin secretion, insulin action, and hepatic insulin extraction, and result in substantial differences in the regulation of glucose metabolism in men and women ${ }^{21}$, although the underlying mechanisms are yet to be elucidated. Second, women seem to have different regulatory mechanisms of RBP4 levels. RBP4 was shown to be associated with gonadotropin concentrations in healthy women and to be higher postmenopausally ${ }^{22}$.

Regarding the effect of covariates on the RBP4-diabetes association, the increased risk of diabetes in those women with higher RBP4 levels seen in the minimally adjusted models was weakened after adjustment for obesity indices. Despite this, higher RBP4 levels were still associated with diabetes in these adjusted analyses, indicating that the RBP4-diabetes association may be somewhat independent of the presence of obesity. On the other hand, we confirmed that the RBP4-diabetes association is not independent of fasting glucose levels, although this result may well reflect over-adjustment of this final model. It has been stated that the RBP4-diabetes association is an artifact of renal function ${ }^{6}$. However, the association in women was little altered by adding estimated glomerular filtration rate to the model. Some associations still need to be better understood, as the somewhat weak negative correlation found between IL-6 and RBP4 levels.

Our study has some limitations. Selection bias, either due to participants not returning for follow-up or not having a sample available for measurement, or to exclusion of those participants with cardiovascular disease, could conceivably have influenced our results. However, we have little $a$ priori reason to believe that the associations here demonstrated should be stronger or weaker among them. Second, we only assessed fasting RBP4 levels, and thus we may not have fully captured the effect of RBP4 in the postprandial period. If so, our findings might underestimate the size of the associations reported. However, it has been recently demonstrated that no significant difference exists in RBP4 plasma concentrations between fasting levels and those $2 \mathrm{~h}$, $4 \mathrm{~h}$ and 6 hours after a high-fat meal intake ${ }^{23}$. This finding suggests that not assessing postprandial RBP4 levels in the present study is probably not an important weakness. Third, errors in RBP4 measurements resulting from long periods of storage are unknown, and could be compromising our ability to measure a true association. Fourth, the fact that the RBP4-diabetes association appeared somewhat weaker in those with impaired fasting glycemia at baseline makes a reverse causality less likely, but, given the multiple stratifications performed and the modest size of the association that we described, we are unable to rule out that RBP4 levels may be linked to type 2 diabetes in a secondary and non-causal manner ${ }^{24}$, Thus, our results must be considered as preliminary at best.

\section{Conclusion}

To our knowledge, this is the first long-term prospective study testing the 
hypothesis that higher plasma RBP4 concentrations predict incident diabetes. Our results suggest that higher RBP4 levels predict type 2 diabetes differently in men and women, and perhaps are important in the development of diabetes in the latter.

Acknowledgments: Funding for this study was provided by the National Institute of Diabetes and Digestive and Kidney
Diseases Grant R01- DK56918 and by National Heart, Lung, and Blood Institute Contracts N01-HC-55015, N01-HC-55016, N01-HC-55018, N01-HC-55019, N01HC-55020, N01-HC-55021, and N01HC-55022. The Brazilian National Council of Technological and Scientific Development (CNPq) provided support for Vivian Luft.

There is no conflict of interest.

\section{References}

1. International Diabetes Federation. Diabetes atlas. Brussels: International Diabetes Federation; 2009.

2. World Health Organization. Preventing chronic diseases: a vital investment. Geneva; 2005.

3. Yang Q, Graham TE, Mody N, Preitner F, Peroni OD, Zabolotny JM et al. Serum retinol binding protein 4 contributes to insulin resistance in obesity and type 2 diabetes. Nature 2005; 436: 356-62.

4. Graham TE, Yang Q, Bluher M, Hammarstedt A, Ciaraldi TP, Henry RR et al. Retinol-binding protein 4 and insulin resistance in lean, obese, and diabetic subjects. $N$ Engl $J$ Med 2006; 354: 2552-63.

5. Chiefari E, Paonessa F, Iiritano S, Le Pera I, Palmieri $\mathrm{D}$, Brunetti G et al. The cAMP-HMGA1-RBP4 system: a novel biochemical pathway for modulating glucose homeostasis. BMC Biol 2009; 7: 24.

6. Henze A, Frey SK, Raila J, Tepel M, Scholze A, Pfeiffer $\mathrm{AF}$ et al. Evidence that kidney function but not type 2 diabetes determines retinol-binding protein 4 serum levels. Diabetes 2008; 57: 3323-6.

7. Janke J, Engeli S, Boschmann M, Adams F, Böhnke J, Luft FC, et al. Retinol-binding protein 4 in human obesity. Diabetes 2006; 55: 2805-10.

8. Duncan BB, Schmidt MI, Pankow JS, Ballantyne CM, Couper D, Vigo A et al. Atherosclerosis Risk in Communities Study. Low-grade systemic inflammation and the development of type 2 diabetes: the atherosclerosis risk in communities study. Diabetes 2003; 52: 1799-805.

9. Duncan BB, Schmidt MI, Pankow J, Bang H, Couper D, Ballantyne CM et al. Adiponectin and the developmen.t of type 2 diabetes - the ARIC Study. Diabetes 2004; 53 : 2473-8.

10. Schmidt MI, Duncan BB, Vigo A, Pankow JS, Couper D, Ballantyne CM et al. Leptin and incident type 2 diabetes: risk or protection? Diabetologia 2006; 49: 2086-96.
11. Levey AS, Stevens LA, Schmid CH, Zhang YL, Castro AF 3rd, Feldman HI et al. A new equation to estimate glomerular filtration rate. Ann Intern Med 2009; 150: 604-12.

12. Collett D. Modelling survival data in medical research. London: Chapman \& Hall; 1994.

13. Graham TE, Kahn BB. Tissue-specific alterations of glucose transport and molecular mechanisms of intertissue communication in obesity and type 2 diabetes. Horm Metab Res 2007; 39: 717-21.

14. Tamori Y, Sakaue H, Kasuga M. RBP4, an unexpected adipokine. Nat Med 2006; 12: 30-1.

15. Broch M, Vendrell J, Ricart W, Richart C, FernandezReal JM. Circulating retinol-binding protein-4, insulin sensitivity, insulin secretion, and insulin disposition index in obese and nonobese subjects. Diabetes Care 2007; 30: 1802-6.

16. Stefan N, Hennige AM, Staiger H, Schleicher E, Fritsche A, Haring HU. Circulating retinol-binding protein-4, insulin sensitivity, insulin secretion, and insulin disposition index in obese and nonobese subjects: response to Broch et al. Diabetes Care 2007; 30: e91.

17. Fernandez-Real JM, Vendrell J, Ricart W, Richart C, Broch M. Circulating retinol-binding protein-4, insulin sensitivity, insulin secretion, and insulin disposition index in obese and nonobese subjects: response to Stefan et al. Diabetes Care 2007; 30: e92.

18. Cho YM, Youn BS, Lee H, Lee N, Min SS, Kwak SH et al. Plasma retinol-binding protein-4 concentrations are elevated in human subjects with impaired glucose tolerance and type 2 diabetes. Diabetes Care 2006; 29: 2457-61.

19. Jia W, Wu H, Bao Y, Wang C, Lu J, Zhu J et al. Association of serum retinol-binding protein 4 and visceral adiposity in chinese subjects with and without type 2 diabetes. $J$ Clin Endocrinol Metab 2007; 92: 3224-9.

20. Lewis JG, Shand BI, Elder PA, Scott RS. Plasma retinolbinding protein is unlikely to be a useful marker of insulin resistance. Diabetes Res Clin Pract 2008; 80: 13-5. 
21. Basu R, la Man C, Campioni M, Basu A, Klee G, Toffolo $\mathrm{G}$ et al. Effects of age and sex on postprandial glucose metabolism: differences in glucose turnover, insulin secretion, insulin action, and hepatic insulin extraction. Diabetes 2006; 55: 2001-4.

22. Makimura H, Wei J, Dolan-Looby SE, Ricchiuti V, Grinspoon S. Retinol-binding protein levels are increased in association with gonadotropin levels in healthy women. Metabolism 2009; 58: 479-87.
23. Ciardi C, Tatarczyk T, Tschoner A, Kranebitter M, Niederwanger A, Ebenbichler CF et al. Effect of postprandial lipemia on plasma concentrations of A-FABP, RBP-4 and visfatin. Nutr Metab Cardiovasc Dis 2009. doi:10.1016/j.numecd.2009.05.013.

24. Ribel-Madsen R, Friedrichsen M, Vaag A, Poulsen P. Retinol-binding protein 4 in twins: regulatory mechanisms and impact of circulating and tissue expression levels on insulin secretion and action. Diabetes 2010; 20: 662-8.

Recebido em: 30/11/11

Versão final apresentada em: 07/06/12

Aprovado em: 10/07/12 